\title{
The Basal Cell Naevus Syndrome: A Case in the Falkland Islands
}

\author{
Maj R Pilcher* \\ BSc, FDSRCPS, RADC \\ Senior Specialist in Oral Surgery
}

Princess Alexandra Hospital, Wroughton, Swindon, Wilts. SN4OQJ

SUMMARY: A case of basal cell naevus syndrome is presented. The jaw cysts were proved histopathologically to be odontogenic keratocysts. The multiple naevoid lesions on the skin were identified as basal cell carcinoma. Intracraniä calcification is illustrated to a degree not previously reported in a case with this syndrome. The importance of identifyin $\vec{B}$ this syndrome is discussed and its presentation in the Falkland Islands is reported.

\section{Introduction}

The basal cell naevus (Gorlin-Goltz) syndrome was first described by Jarisch in 1894 (1): the paper by Gorlin and Goltz was published in 1960 (2) with a review by Gorlin in 1987 (3). Two Egyptian skeletons of the Early Dynastic period have been shown to have bony anomalies compatible with this diagnosis (4).

The syndrome shows autosomal dominant inheritance with no sex predilection, variable expressivity and high penetrance in up to $50 \%$ of cases (5).

Gorlin and Goltz described a case with multiple jaw cysts, multiple basal cell naevi on the back and face, and bifid ribs. Since then other reports have added other anomalies associated with the syndrome which are summarised as follows:

(a) Cutaneous anomalies: including basal cell naevi, benign dermal cysts and tumours, palmar pitting, palmar and plantar keratosis and dermal calcinosis. The basal cell naevi may appear at birth or be first noted in infancy. Occasionally they may begin at about puberty and gradually increase in size and number over a period of years. There may be few or several hundred and there is a tendency for bilateral distribution, but this need not be symmetrical. The size of the individual lesion varies from that of a pinhead to approximately $5 \mathrm{~mm}$ in diameter. Pedunculated and papular lesions are common on the neck, eyelids and axillae. The colour is that of the surrounding skin although they may be hyperpigmented. The individual lesions are elevated, firm, symptomless, and painless to touch. Their surface is smooth and occasionally may be covered by minute blood vessels. Their distribution varies the commonest areas being the trunk and extremities. Although aggressive behaviour may occur resulting in gross destruction the majority behave in a benign fashion. A lesion which has ulcerated is a sign of aggressive change. They may closely resemble the appearance of neurofibromatosis. The following features may precede the appearance of the skin lesions.

(b) Dental and osseous anomalies including multiple jaw cysts, mild mandibular prognathism, cleft lip and palate, rib anomalies (often bifid), vertebral anomalies and brachymetacarpalism. The jaw cysts are the most common characteristic of the syndrome. They may ge simple occurring close to the apex of a tooth, dentigerous containing a tooth or primordial (odontogende keratocyst). They may develop by the 7 th year of age and are usually located in the premolar-molar area resulting in displacement of the child's teeth. Mandibular cysts afe more common than maxillary cysts and often secondary infection prompts oral surgical attention. Ballooning and weakening of the bone may cause deformity pathological fractures.

(c) Ophthalmologic abnormalities inclufing hypertelorism with wide nasal bridge, conge fital blindness and internal strabismus.

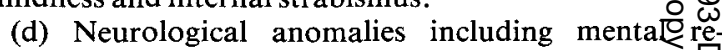
tardation, dural calcification, agenesis of the coips callosum, congenital hydrocephalus and an increas incidence of medulloblastomas.

(e) Sexual abnormalities including hypogonadism males and ovarian tumours in females (6).

A relationship to pseudohypoparathryoidism has be $\vec{f}$ suggested due to the lack of response to parathormone and the shortened fourth metacarpals found in son patients (7).

Histologically the basal cell naevi are identical to basal cell carcinoma. Clinically they differ by theif multiplicity, their early age at appearance and capabilify for rapid growth and central erosion.

The odontogenic keratocysts of the jaw show a high incidence of recurrence following removal and are :att increased risk of association with malignancy such $3 \mathrm{~s}$ fibrosarcoma (8-10), ameloblastoma (11), squamous cell carcinoma (12-13), leiomyoma (14-15) and spindle cêl carcinoma (16). These cases illustrate the potentially highly destructive nature of the keratocyst being capable of destroying a major part of the facial skeleton wif involvement of the orbit and contents.

\section{Case Report}

A 56 year old Caucasian male farmworker of the Falkland Islands presented complaining of a painfer 


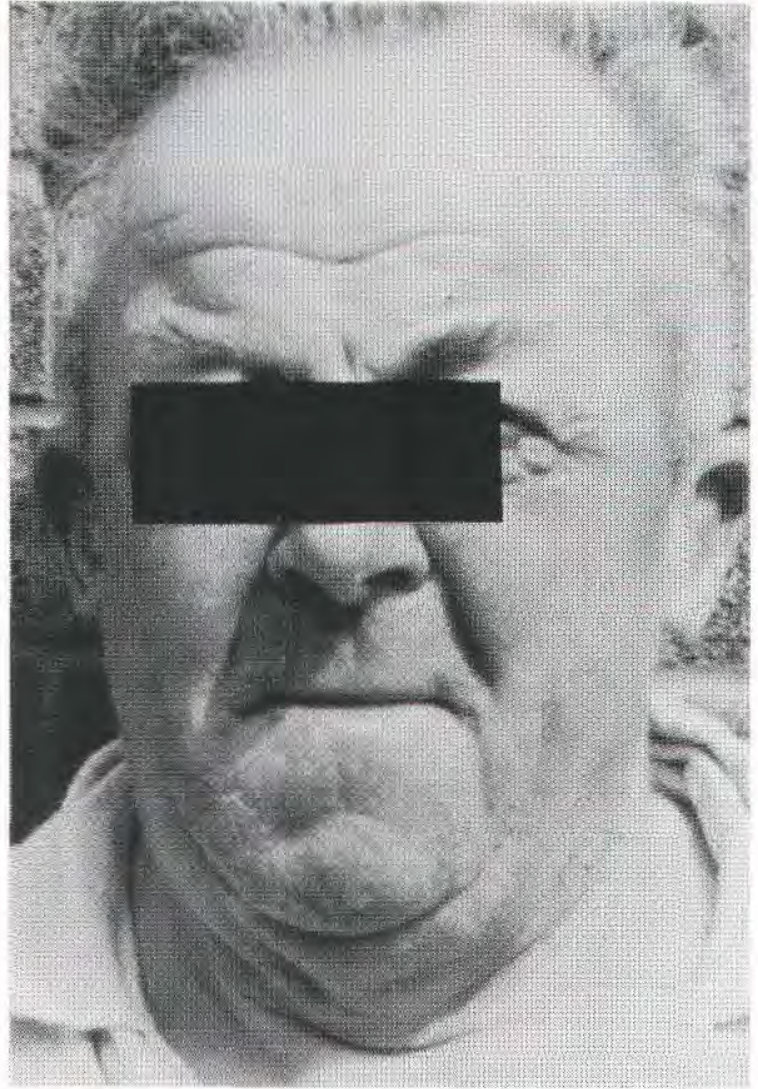

Fig 1. Characteristic facies of Gorlin-Goltz syndrome.

swelling in the right body of his mandible and an associated purulent intra-oral discharge. He had previously been unaware of any abnormality in this region. He was generally fit. He recalled removal of a jaw cyst in Argentina from the left side of his mandible about fifteen years earlier and removal of multiple basal cell carcinoma from his face and temple ten years previously and from his face and back three years previously. There was no known relevant family history.

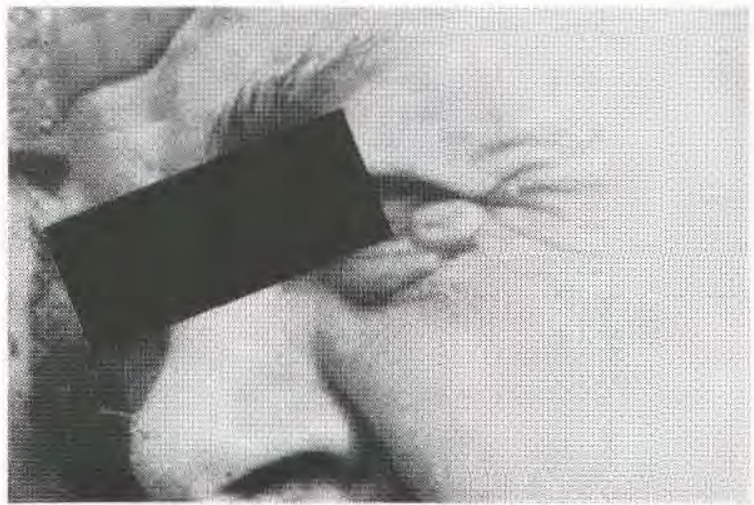

Fig 2. Basal cell naevus on lower left eyelid.
Clinical findings were a characteristic facies with bossing of frontal and parietal bones, well developed 3 supraorbital ridges, heavy eyebrows, hypertelorism, a $\underset{\mathbb{\Phi}}{\Omega}$ broad nasal root, hypoplasia of the maxilla and mild $\Omega$ prognathism (Fig 1). Naevi were present on both left and right eyelids (Fig 2) and he had an epidermoid cyst on his?.? left forearm.

$\overrightarrow{\overrightarrow{0}}$

Radiographic findings included multilocular cystic $\stackrel{\vec{F}}{\stackrel{5}{+}}$ lesions not only in the right body of his mandible (Fig 3)을 but also in the other three jaw quadrants (Fig 4). Intracranial calcification consisted of lamelliform calcification of the falx cerebri and the tentorium $\mathbb{\Phi}$ cerebelli, calcification of the wall of the superior sagittalœ sinus and calcification of the arachnoid granulations $\overrightarrow{0}$ (Fig 5). Calcification of the sella turcica was also present.

Routine haematology and biochemical investigations $\vec{\omega}$ were within normal limits including repeated serum cal-? cium and phosphate levels.

Under endotracheal general anaesthesia the naevi were excised and the cysts enucleated. The left maxillary sinus $\vec{\omega}$ was found to be largely destroyed. There was no involvement of the orbit.

Histopathological examination confirmed that the skin lesions were basal cell carcinoma (Fig 6). The jawo cysts in all four quadrants proved to be odontogenif? keratocysts. They had a lumen containing epithelo/c debris and a lining of stratified squamous epithelium $\bar{\Phi}$ (f) about 6-8 layers thick which had a parakeratinised siक face; there was a prominent basal cell layer and a sug: epithelial layer containing a chronic inflammatory $\overrightarrow{\text { Tif }} \overrightarrow{0}$ filtrate (Fig 7).

No other cases were identified in his blood relativ The patient currently had no plans for marriage orẹ have offspring. Advice was given regarding avoiding s? exposure, wearing protective clothing and the use of sunscreens. Long term review of the patient and relevanto relatives was arranged.

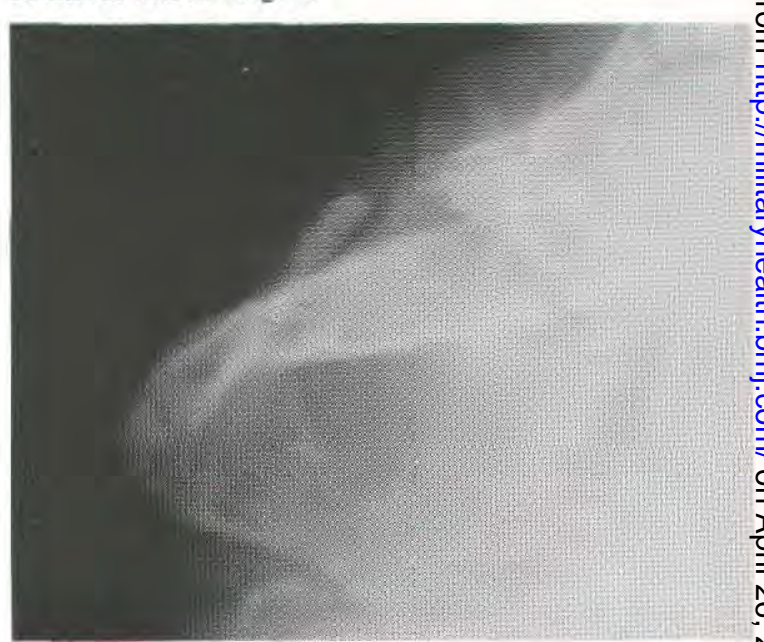

Fig 3. Lateral oblique radiograph of right mandible showing multilocular radiolucency. 


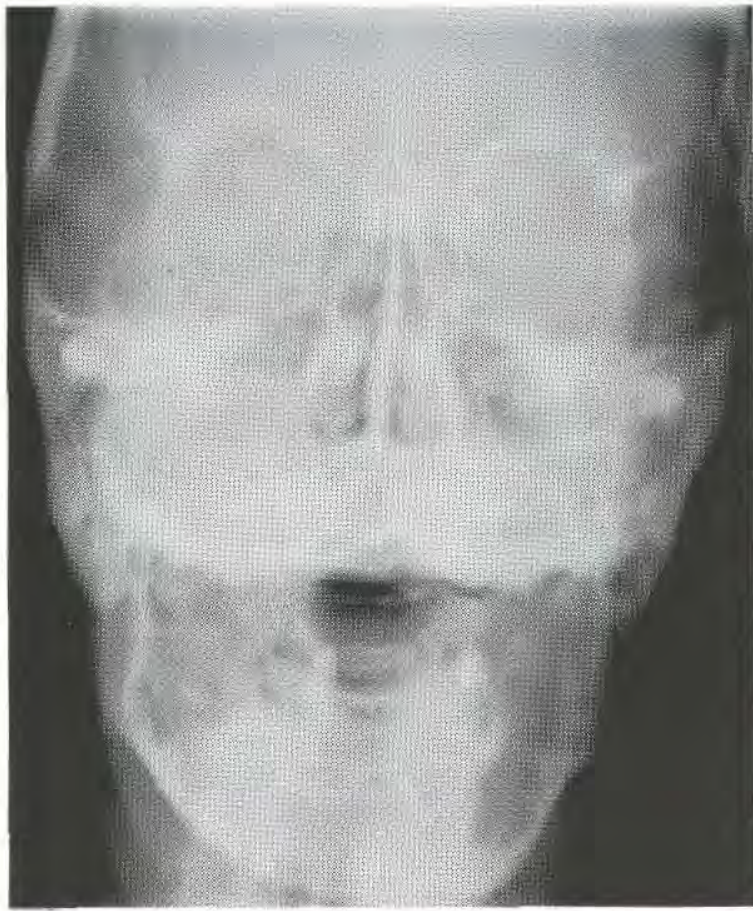

Fig 4. PA face showing multilocular radiolucencies in all four jaw quadrants.

\section{Discussion}

Earlier diagnosis of this patient as having basal cell naevus syndrome had not been made despite having had multiple basal cell carcinoma excised on previous occasions. It is important in any patient presenting with multiple basal cell carcinoma to rule out the presence of this syndrome; this is because of the many associated problems which these patients may eventually face and the necessity to screen for other abnormalities which may be already present in the patient or relatives. Long term review must be arranged and genetic counselling organised.

Management of the basal cell carcinomata should be by excision. Mohs micrographic surgery (17) is indicated in the treatment of basal cell carcinoma arising in high risk areas particularly around the eyes and lips: the area macroscopically involved is removed after initial debulking or currettage, and divided for processing. The resected tissue and the surrounding skin are marked with ink and the edges of the tumour pieces are coded with dyes to aid orientation. A precise map showing the coded tissue segments in relation to the local anatomy is constructed. Tissue is subsequently processed taking horizontal rather than vertical sections allowing examination of $100 \%$ of the tumour base. Any remaining tumour can be clearly identified on the slide, the map and the patient enabling a second stage of excision to be directed specifically to the residual tumour leaving normal skin

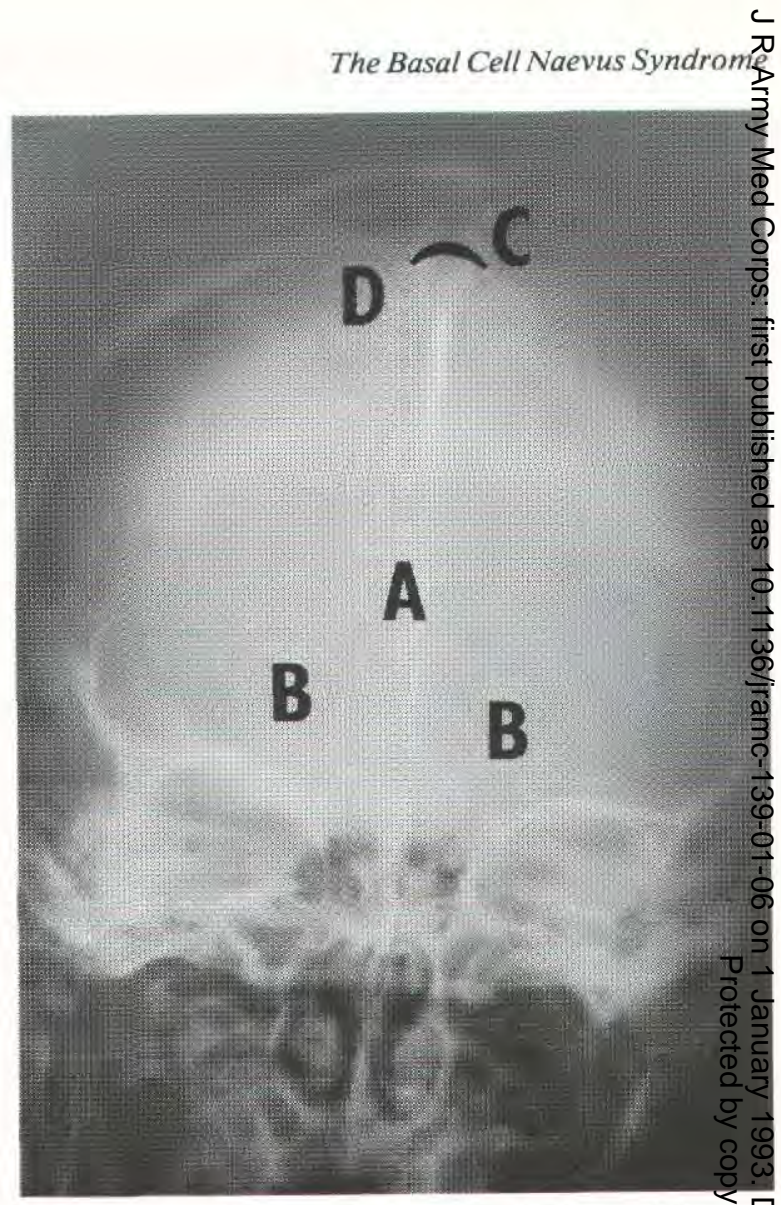
A Lamelliform calcification of falx cerebri
B Calcification of tentorium cerebelli
C Calcification of superior sagittal sinus
D Calcification of arachnoid granulations

Fig 5. PA skull showing calcification of the falx cerebr tentorium cerebelli, superior sagittal sinus ang arachnoid granulations.

unscathed. When the basal cell carcinoma are to numerous to excise they must be watched closely and removed selectively when they threaten the patient b becoming large and ulcerated (18).

Radiotherapy for multiple lesions should be avoide as irradiation of the skin in this population leads to striking increase in the number of basal cell carcinomato within the treated field (19-20). A further contrain 3 dication is that radiotherapy may promote malignari changes in jaw lesions which are in the radiation field (3) and 13 ).

Systemic retinoids have been shown to cause re gression of the basal cell carcinomata and to decrease tho rate of appearance of new lesions; however baseline ac tivity quickly returns after discontinuation of therapo (21). Intralesional sustained release interferon has been used with some success (22).

Management of the odontogenic keratocysts 


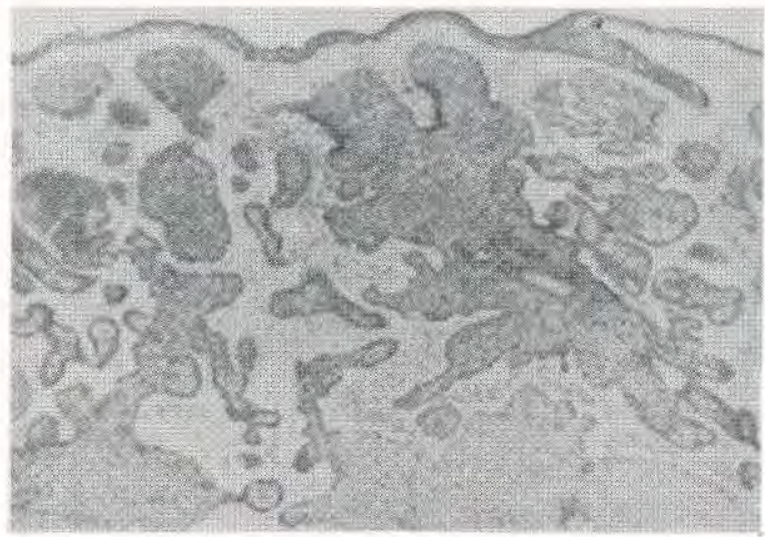

Fig 6. Basal cell carcinoma from lower left eyelid. H\&E $x$ 190.

complicated by their tendency to recur. Suggested mechanisms by which they recur include the presence of satellite cells, increased mitotic activity of the cyst lining epithelial cells and increased collagenolytic and fibrinolytic activity of the cyst walls (23-27). Friability of the lining and difficulty in completely removing the cyst may also be a causal factor.

Browne (28) found there was no significant difference in the recurrence rate following treatment by three basic methods: marsupialisation, enucleation and primary closure, or enucleation and packing the wound open. $\mathrm{He}$ concluded that the rate or recurrence was related to the nature of the lesion and not to the method of treatment. Voorsmit (29) advocates the use of Carnoy's solution in the cyst prior to enucleation. Ahlfors et al (30) advocate that the lesion be regarded as a benign cystic tumour rather than a developmental or other type of cyst and that it is more aggressive when associated with this syndrome. They suggest marginal resection including a rim of uninvolved bone, similar to the treatment in cases of unicystic ameloblastoma. Adherence of the cyst to overlying mucosa may also require excision of this part of the mucosa. Mustaciulo et al (31) described enucleation of extensive keratocysts initially; rather than resection, thus maintaining the integrity of the mandible. The subsequent bony healing provided greater substance to the mandible allowing treatment of recurrence by block resection without involving the inferior border. McLoughlin et al (32) advocate aggressive surgery at an early stage of cyst development.

Long term review of the patient together with screening and long term review of relevant relatives plus genetic counselling will reduce both the morbidity and mortality attributable to the syndrome.

The presence of this syndrome in the Falkland Islands has not previously been reported.

\section{Acknowledgements}

I would like to thank Gp Capt K F Ashley OBE,

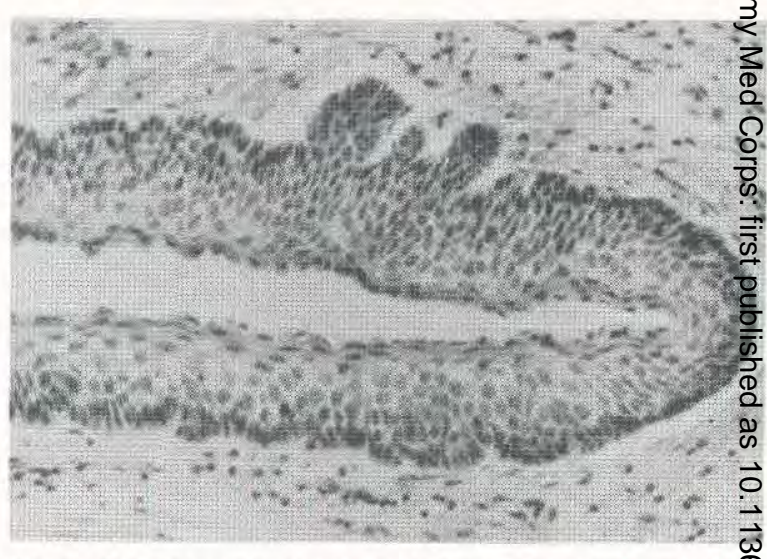

Fig 7. Odontogenic keratocyst lining from left maxills H\&E x 190.

Consultant Oral and Maxillofacial surgeon for permis sion to report on his patient.

My thanks also for the help given by Mr T B Barne오 Dental Officer, King Edward VII Memorial Hospitab Falkland Islands and the Medical illustrations depar? ment Royal Army Medical College Millbank.

\section{REFERENCES}

1. JARISCH W. Zur lehre von den Hautgeschwuls Arch Dermatol Syphil 1894; 28: 163-222.

2. GORLIN R J, Goltz R W. Multiple naevoid bå̊ cell epithelioma, jaw cysts and bifid rib웅 syndrome. NEngl JMed 1960; 262: 908.

3. GORLIN R J. Naevoid Basal Cell Carcin o Syndrome. Medicine 1987; 66: 98.

4. Satinoff M I, Wells C. Multiple basal cell naeviő syndrome in Ancient Egypt. Med Hist 1969; 130 294.

5. LOREnZ R, Fuhrmann W. Familial basal cell nevi $\overrightarrow{\vec{Q}}$ syndrome. Hum Genet 1978; 44: 153-163.

6. Shafer W G, Hine N K, Levy B N. Textbook o oral pathology. 4th Ed. Philadelphia and Londor. Saunders.

7. Block J B, Clendenning W E. Parathyroi hormone hyporesponsiveness in patients with bas cell nevi and bone defects. $N$ Engl J Med 1963;268 1157.

8. Binkley G W, Johnson H H. Epithelioma Ade noides Cysticum: Basal cell nevi, agenesis of tho corpus callosum and dental cysts, Arch Derm Syp $\underset{\mathbb{E}}{ }$. 1951; 63: 73.

9. Howell J B, CARo M R. The basal cell nevus syndrome. AMA Arch Dermatol 1959; 79: 67.

10. REED J C. Nevoid basal cell carcinoma syndrom with associated fibrosarcoma of the maxilla. Arc Dermatol 1968; 97: 304 .

11. Gorlin R J, PindBorg J J, Cohen M M. Syndrome of the head and neck. 2nd Ed. 1976, pp. 520-52\%? New York: McGraw-Hill Book Company.

12. RamSDEN R T, BarRetT A. Gorlin's syndrome. Laryngol Otol 1975;89(6): 615 . 
13. Moos K F, Rennie J S. Squamous cell carcinoma arising in a mandibular keratocyst in a patient with Gorlin's syndrome. Br J Oral Maxillofac Surg 1987; 25: 280-284.

14. KaHN L B, GoRdon W. Basal cell naevus syndrome. $S$ Afr Med J 1967; 41: 832.

15. TAylor W B, ANDERSON D E, Howell J B, Thurston C S. The nevoid basal cell carcinoma syndrome. Ann of Dermatol 1968;97: 612.

16. Shapiro M J. Basal cell nevus syndrome: A case report with associated carcinoma of the maxilla. Laryngoscope 1970; 80: 777.

17. Swanson N A, Grekin R C, Baker S R.Mohs surgery: techniques, indications and applications in head and neck surgery. Head Neck Surg 1983; 6: 683.

18. Totten J R. Multiple basal cell naevi syndrome: management of the young patient. Br J Oral Surg 1979; 32: 50.

19. SAMS W M, LyNCH P J. Principles and Practice of Dermatology. Churchill Livingstone 1990. 1st Ed. 211-212.

20. Grosch E J, Lambert $H$. The treatment of difficult cutaneous basal and squamous cell carcinomata with electrons. Br J Radiol 1979; 52: 472.

21. Bollag W. Prophylaxis of chemically induced epithelial tumours with an aromatic retinoic acid analogue. Eur J Cancer 1975; 11: 721.

22. Edwards L, Tucker S B, Perednia D, et al. The effect of an Intralesional Sustained-Release Formulation of Interferon Alfa-26 on Basal Cell
Carcinomas. Arch Dermatol 1990; 126: 1029-1032

23. Rud J, Pindborg J J. Odontogenic keratocysts follow-up study of 21 cases. J Oral Surg 1980; 27: 323.

24. Donoff R B, Harper E, Guralnick W C. CGlagenolytic activity in keratocysts. J Oral Surg 197.2; 30: 879 .

25. AtTENBORough N-R. Recurrence of an odontogerific keratocyst in bone graft: report of a case. $B r J O E l$ Surg 1974; 12: 33.

26. MAGNusson B C. Odontogenic keratocysts: clinical and histological study with special referen to enzyme histochemistry. J Oral Pathol 1978; 7: 8

27. Vedtofte P, Praetorius F. Recurrence of the odontogenic keratocyst in relation to clinical a $\overrightarrow{\mathrm{B}} \mathrm{d}$ histological features. Int J Oral Surg 1979; 8: 412:-

28. BrownE R M. The odontogenic keratocyst. Clinieal aspects. Br Dent J 1976; 3: 225.

29. Voorsmit R A C A, Stoelinga P J W, VAN HaElāత U J G M. The management of keratocysts. J Mog illofac Surg 1981; 9: 228.

30. Ahlfors A, Larsson A, Sjogrens S. The odo togenic keratocyst: a benign cystic tumour. $J O \notin g$ Maxillofac Surg 1984 42: 10.

31. Mustaciulo V W, Brahney C P, Aria A A. F current keratocysts in Basal Cell Nevus Syndronae. J Oral Maxillofac Surg 1989; 47: 870-873.

32. Mcloughlin P M, Dickensen A J, Avery $\vec{B} \vec{s}$. Gorlin's syndrome and von Recklinghausen'sodssease occurring in one family. Br J Oral Maxil Surg 1991; 29: 189-193. 